\title{
Increased Nitrous Oxide Emissions Resulting from Nitrogen Addition and Increased Precipitation in an Alpine Meadow Ecosystem
}

\author{
Yangong Du ${ }^{1,2 *, 3}$, Xiaowei Guo ${ }^{2,4}$, Guangmin $\mathrm{Cao}^{2},{\text { Yikang } \mathrm{Li}^{2}}^{2}$ \\ ${ }^{1}$ Key Laboratory of Mountain Surface Processes and Ecological Regulation, \\ Institute of Mountain Hazards and Environment, Chinese Academy of Sciences, Chengdu 610041, China \\ ${ }^{2}$ Key Laboratory of Adaptation and Evolution Plateau Biota, Northwest Institute of Plateau Biology, \\ Chinese Academy of Science, Xining 810008, China \\ ${ }^{3}$ NSW Department of Industry, Skills and Regional Development, Wagga Wagga Agricultural Institute, \\ NSW 2650, Australia \\ ${ }^{4}$ Graham Centre for Agricultural Innovation \\ (an alliance between NSW Department of Industry and Charles Sturt University, \\ Wagga Wagga, NSW 2650, Australia)
}

Received: 20 April 2015

Accepted: 30 November 2015

\begin{abstract}
The effects of nitrogen $(\mathrm{N})$ addition and increased precipitation on nitrous oxide $\left(\mathrm{N}_{2} \mathrm{O}\right)$ emissions in alpine meadow ecosystems are still unclear. In this study, we measured $\mathrm{N}_{2} \mathrm{O}$ fluxes on the Tibetan plateau under interactions of moderate atmospheric $\mathrm{N}$ deposition and increased precipitation using a closed chamber method. Under all applied treatment conditions, the alpine meadow ecosystem acted as a source of $\mathrm{N}_{2} \mathrm{O}$. The $\mathrm{N}_{2} \mathrm{O}$ emission rate reached a maximum of $74.83 \pm 14.40 \mu \mathrm{g} \mathrm{m}^{-2} \mathrm{~h}^{-1}$, with a significant increase in emission rate of $68.76 \%$ following $\mathrm{N}$ addition when compared with the control plot $(\mathrm{p}<0.05)$. Increased precipitation, and its interactive combination with $\mathrm{N}$ deposition, enhanced the $\mathrm{N}_{2} \mathrm{O}$ emission rate by $53.90 \%$ and $44.52 \%$, respectively. However, there was no significant difference between these two treatments. Increased precipitation would help to mitigate $\mathrm{N}_{2} \mathrm{O}$ fluxes under global nitrogen deposition conditions.
\end{abstract}

Keywords: nitrous oxide, $\mathrm{N}$ deposition, increased precipitation, alpine meadow

\section{Introduction}

An increase in the quantity of reactive nitrogen in the atmosphere, together with increased precipitation, alters soil chemistry and the physiology of soil microbes, and influences the balance of the greenhouse gas $\mathrm{N}_{2} \mathrm{O}[1,2]$.

*e-mail: ygdu@nwipb.cas.cn
Annual bulk $\mathrm{N}$ deposition across China increased by approximately $7.9 \mathrm{~kg} \mathrm{ha}^{-1}$ between 1980 and 2010, with a value of $21.1 \mathrm{~kg} \mathrm{ha}^{-1}$ during the latter year [2]. Glaciers melted and shrank by $7 \%$ (about $3.79 \times 10^{3} \mathrm{~km}^{2}$ ) during the period 1960-2005, and precipitation gradually increased during peak growing seasons, with a notable 14\% increase in precipitation per decade in Tibet [3]. Under longterm medium soil moisture conditions, $\mathrm{N}_{2} \mathrm{O}$ is dominant, with $\mathrm{N}_{2}$ mostly emitted from saturated soil [1]. Aerobic 
nitrification and anaerobic denitrification are responsible for soil $\mathrm{N}_{2} \mathrm{O}$ production $[1,4]$.

Nitrogen deposition had been shown to increase $\mathrm{N}_{2} \mathrm{O}$ emissions; the relationship between the two variables was not found to be significant on alpine meadows but had been shown to be significant in alpine grasslands during the growing season $[5,6]$. Average $\mathrm{N}_{2} \mathrm{O}$ flux had increased by $25.56 \%$ following the application of $10 \mathrm{~g} \mathrm{~N} \mathrm{~m}^{2} \mathrm{y}^{-1}$ in semi-arid grassland [7]. Irrigation was found to have only a small effect on yearly emissions during normal years, but had enhanced emissions by $70 \%$ during dry years [1]. Rainfall-stimulated $\mathrm{N}_{2} \mathrm{O}$ emissions on corn farmland and increased precipitation could exert a greater influence on $\mathrm{N}_{2} \mathrm{O}$ emissions in grassland soils $[1,6,7]$.

The Tibetan Plateau is known as the birthplace of the Asian primary rivers, and it is in the part of the world with even fastest change in terms of global change, then alpine meadow, as one of the most important dominant vegetation types, expanded $35 \%$ of the Tibetan Plateau [4]. The interactive effects of $\mathrm{N}$ deposition and precipitation on $\mathrm{N}_{2} \mathrm{O}$ fluxes in alpine meadow are still poorly understood [1]. It is possible that increased ammonia and nitrate, combined with precipitation, directly promote soil redox potential and influence the microbial-mediated process of $\mathrm{N}_{2} \mathrm{O}$ production and emission [6].

To verify whether this is the case, we conducted $\mathrm{N}_{2} \mathrm{O}$ flux measurements from May to October 2012 on an alpine Kobresia humilis meadow on the Tibetan plateau. This study aims to further scientific understanding of $\mathrm{N}$ deposition and of the impact of increased precipitation on $\mathrm{N}_{2} \mathrm{O}$ balance, thus aiding in the evaluation of $\mathrm{N}$ deposition effects and climate change.

\section{Material and Methods}

\section{Site Description}

The study site was located at the Haibei national alpine meadow research station $\left(37^{\circ} 32^{\prime} \mathrm{N}, 101^{\circ} 15^{\prime} \mathrm{E} ; 3250 \mathrm{~m}\right.$ altitude) within an alpine $K$. humilis meadow located at the northeast edge of the Qinghai-Tibetan plateau. The climate of the site was dominated by the southeast monsoon and by the high-pressure system of Siberia. Annual average air temperature was approximately $-1.7^{\circ} \mathrm{C}$, with extreme maximum and minimum temperatures of $27.6^{\circ} \mathrm{C}$ and $-37.1^{\circ} \mathrm{C}$, respectively. Annual precipitation at the Haibei station for the normal year reached about $560 \mathrm{~mm}, 80 \%$ of which fell during the short summer growing season from May to September. Average annual sunlight was $2462.7 \mathrm{~h}$, representing $60.1 \%$ of total possible sunshine [8]. Average annual precipitation in 2012 was approximately $380 \mathrm{~mm}$.

The soil within the study area was a clay loam MatGryic Cambisol, with a mean thickness of $0.65 \mathrm{~m}$ and high organic content of approximately $5.5 \%$ and $3.3 \%$ at 0-10 $\mathrm{cm}$ and $10-20 \mathrm{~cm}$ soil depths, respectively. Soil bulk density was $0.75 \mathrm{~g} \mathrm{~cm}^{-3}$ and $1.11 \mathrm{~g} \mathrm{~cm}^{-3}$ at $0-10 \mathrm{~cm}$ and 10-20 cm soil depths, respectively (Table 1).

The study site was used as winter pasture for local sheep and yaks, with an average grazing intensity of 2.55 sheep $\mathrm{ha}^{-1}$ since 1982 . Average aboveground plant living biomass was $340 \mathrm{~g} \mathrm{~m}^{-2}$ in August $[8,9]$. The biotic community included more than 40 species $\mathrm{m}^{-2}$ and was dominated mainly by the perennial sedges Kobresia humilis Serg., Stipa aliena Keng., Festuca ovina Linn., Poa spp. Linn., Gentiana straminea Maxim., Elumus nutants Griseb., and Polygonum viviparum Linn.

We state clearly that no specific permissions were required for our locations or activities, and provide details on why this is the case, and confirm that the field studies did not involve endangered or protected species. This research did not refer to vertebrate studies.

\section{Experimental Treatments}

Four treatments, with three replications in each case, were set up on the Kobresia humilis meadow in May 2012. The first treatment $(\mathrm{N})$ involved simulated nitrogen deposition at $2 \mathrm{~g} \mathrm{~N} \mathrm{~m}^{-2}$ of $\mathrm{NH}_{4} \mathrm{NO}_{3}$ and most closely approximated the perennial averaged observation of nitrogen deposition at this station. The second treatment (Pre) involved the addition of $20 \%$ of the amount of perennial averaged precipitation. The third treatment $(\mathrm{N} \times$ Pre) comprised the interaction of the first two treatments, while the fourth treatment (CK) was a control, i.e., no actual treatment was applied. Each plot covered an area of $1 \mathrm{~m}^{2}$ and was divided into two equal portions, one for the growing season (May to September) and the other for the period of dormancy. Over the growing season, nitrogen and water were added on the last day of every month in six equal doses, while during the dormancy period all applications were provided on a single occasion in October. During each application, $\mathrm{NH}_{4} \mathrm{NO}_{3}$ was weighed, dissolved in water, and applied to each plot using a sprayer. Two passes were conducted to ensure even distribution. The control plot received the same amount of

Table 1. Basic soil properties of alpine meadow.

\begin{tabular}{|c|c|c|c|c|}
\hline Soil depth $(\mathrm{cm})$ & $\mathrm{pH}$ & Organic C (\%) & Field WHC $(\%)$ & Bulk density $\left(\mathrm{g} \mathrm{cm}^{-3}\right)$ \\
\hline $0-10$ & $7.3 \pm 0.4$ & 5.5 & 53.6 & $0.75 \pm 0.05$ \\
\hline $10-20$ & $7.4 \pm 0.5$ & 3.3 & & $1.11 \pm 0.09$ \\
\hline $20-30$ & & 2.7 & 35.9 & $1.13 \pm 0.04$ \\
\hline $30-40$ & & 1.9 & & $1.15 \pm 0.03$ \\
\hline
\end{tabular}


water as the experimental plots but with no addition of nitrogen. To avoid disturbing other elements, dissolved phosphorus and potassium were simultaneously used for fertilization in adequate amounts.

\section{Sample Collection and Measurement}

Nitrous oxide emissions were measured using a static chamber method and gas chromatograph (HP4890D, Agilent) with electron capture detector [4]. Preexperimental sampling at $2 \mathrm{~h}$ intervals showed that the flux rate between 0900 and $1000 \mathrm{~h}$ local time was close to that of the diurnal average [9]. Gas samples were collected from the chambers every $10 \mathrm{~min}$ over a $30 \mathrm{~min}$ period using $100 \mathrm{ml}$ plastic syringes; measurements took place immediately after. The accuracy of the sample analysis was approximately $\pm 5 \times 10^{-9} \mathrm{~L} \mathrm{~L}^{-1}$ in the case of $\mathrm{N}_{2} \mathrm{O}$ measurements.

\section{Calculation and Statistical Analysis of Data}

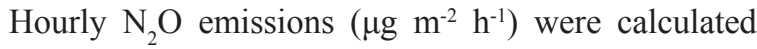
based on the slope of linear increase in concentrations over the sampling period, as follows:

$$
F_{N_{2} O}=\rho \times \frac{V}{A} \times \frac{P}{P_{0}} \times \frac{T_{0}}{T} \times \frac{d C_{t}}{d t}
$$

...where $\mathrm{F}$ is the hourly emission rate $\left(\mu \mathrm{g} \mathrm{m}^{-2} \mathrm{~h}^{-1}\right)$ and $\mathrm{V}$ and $\mathrm{A}$ are the volume and ground area covered by the chamber, respectively. $\mathrm{C}_{t}$ denotes $\mathrm{N}_{2} \mathrm{O}$ concentration in the chamber at time $\mathrm{t}$, and $\rho$ is air density inside the chamber. $\mathrm{T}_{0}$ and $\mathrm{P}_{0}$ represent air pressure and temperature under standard conditions (with values of $1.103 \times 10^{4} \mathrm{~Pa}$ and $273 \mathrm{~K}$, respectively). $\mathrm{P}$ and $\mathrm{T}$ are local air pressure and temperature in the chamber, respectively.

\section{Statistical Analysis}

The coefficient of variation was analyzed by means of the following equation: (standard deviation/mean value) $\times 100 \%$. The effects of treatments and their interaction were analyzed using two-way analysis of variance (ANOVA). Critical least significant difference (LSD) values were calculated post-hoc using SPSS 16.0 (System Software Inc.) at a 5\% level of error probability.

\section{Result}

\section{Effect of Nitrogen Addition and Increased Precipitation on $\mathrm{N}_{2} \mathrm{O}$ Fluxes}

The plots used for alpine meadow ecosystem treatments acted as sources of $\mathrm{N}_{2} \mathrm{O}$. During the growing season, the emission rate from the plots to the atmosphere averaged approximately $44.34 \pm 9.67 \mu \mathrm{g} \mathrm{m}^{-2} \mathrm{~h}^{-1}$ (in the case of CK), $74.83 \pm 14.40 \mu \mathrm{g} \mathrm{m}^{-2} \mathrm{~h}^{-1}(\mathrm{~N}), 68.24 \pm 22.32 \mu \mathrm{g} \mathrm{m}^{-2}$ $\mathrm{h}^{-1}$ (Pre), and 64.08 $\pm 22.22 \mu \mathrm{g} \mathrm{m}^{-2} \mathrm{~h}^{-1}(\mathrm{~N} \times$ Pre) (Fig. 1). The $\mathrm{N}_{2} \mathrm{O}$ emission rate following nitrogen deposition (N) increased significantly by $68.76 \%$ when compared with the control plot $(p<0.05)$. Precipitation increases (Pre) and combined precipitation increase and nitrogen addition $(\mathrm{N} \times$ Pre $)$ enhanced the $\mathrm{N}_{2} \mathrm{O}$ emission rate by $53.90 \%$ and $44.52 \%$, respectively. However, there was no significant difference between the two treatments (Fig. 1). Precipitation increases would help to mitigate future $\mathrm{N}_{2} \mathrm{O}$ fluxes under conditions of global nitrogen deposition.

\section{Seasonal Variations in $\mathrm{N}_{2} \mathrm{O}$ Emission Rates on the Alpine Meadow}

Variations in $\mathrm{N}_{2} \mathrm{O}$ emissions did not exhibit a clear seasonal pattern. There were two emission peaks, one at the end of June and the other at the beginning of August. Nitrogen deposition tended to increase $\mathrm{N}_{2} \mathrm{O}$ emissions from late June to July and in September. On the August $6, \mathrm{~N}_{2} \mathrm{O}$ emission rates resulting from Pre and $(\mathrm{N} \times$ Pre $)$ treatments were significantly higher than those produced

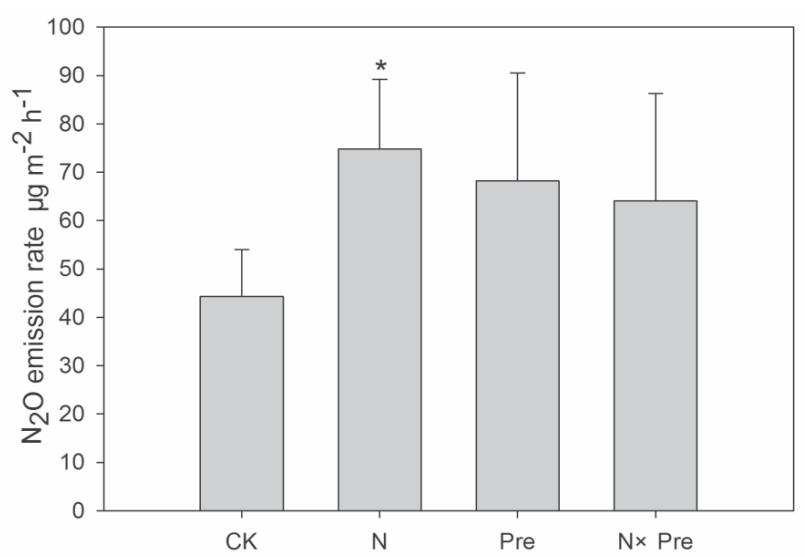

Fig. 1. Average nitrous oxide emission fluxes during the growing season under different treatment conditions. Means \pm standard errors are presented.

* indicates a significant difference among the four plots.

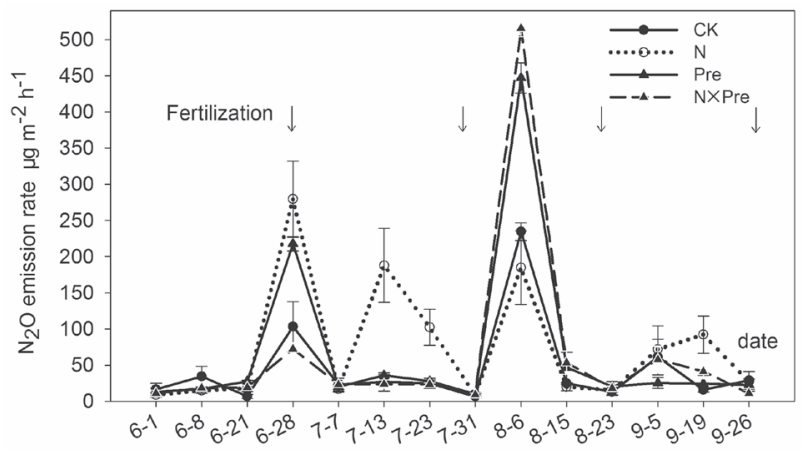

Fig. 2. Nitrous oxide emission rates under different treatment conditions on different dates. Means \pm standard errors are presented. 
from $\mathrm{N}$ and $\mathrm{CK}$ plots $(\mathrm{p}<0.05)$. The highest emission flux recorded was $515.50 \pm 11.48 \mu \mathrm{g} \mathrm{m}^{-2} \mathrm{~h}^{-1}$, and it occurred at the beginning of August and resulted from the $\mathrm{N} \times$ Pre treatment. A significant priming effect after fertilization and precipitation increases was noted during one week in the period spanning July to September, at the time of application of the nitrogen fertilization treatment in June (Fig. 2). This study indicated very high inherent spatial variability of $\mathrm{N}_{2} \mathrm{O}$ fluxes in all experimental plots, with an average coefficient of variation.

\section{Discussion}

\section{Simulation of Nitrogen Deposition and Precipitation Increase on $\mathrm{N}_{2} \mathrm{O}$ Emissions}

The addition of nitrogen generally increased $\mathrm{N}_{2} \mathrm{O}$ emission rates in grassland and meadow ecosystems [10, 11].The soil nitrogen pool is expected to play an important role in regulating $\mathrm{N}_{2} \mathrm{O}$ emissions $[12,13]$. Such a trend was also noted in this study, possibly driven by the following two factors. First, nitrogen fertilization significantly promotes grassland primary production [5], while grassland root exudation, secretion, and cell slough could provide carbon and energy sources for microorganisms [4]. In addition, alpine meadow ecosystems are limited by nitrogen availability and by the abundance of mineral nitrogen $\left(\mathrm{NH}_{4}^{+}\right.$and $\left.\mathrm{NO}_{3}^{-}\right)$in the microorganism substrate. Both of these factors would likely stimulate alpine meadow soil $\mathrm{N}_{2} \mathrm{O}$ fluxes $[4,14]$.

Summer $\mathrm{N}_{2} \mathrm{O}$ fluxes followed an upward trend, with higher values related to precipitation in subalpine ecosystems [12]. This study revealed that, during the relatively dry year of 2012 (during which annual precipitation was approximately $380 \mathrm{~mm}$ ), an increase in precipitation increased $\mathrm{N}_{2} \mathrm{O}$ emissions from alpine meadow ecosystems by $53.90 \%$. The soil $\mathrm{N}_{2} \mathrm{O}$ flux increased by $70 \%$ in irrigation-enhanced Hungarian sandy and loess grasslands of a dry year [1]. When soil is wellaerated, the oxidative nitrification process dominates, resulting in nitrous oxide emissions [10]. An increase in growing season precipitation enhances grassland soil $\mathrm{N}_{2} \mathrm{O}$ emissions through the denitrification process, due to the presence of an applied fertilizer $\mathrm{N}$ substrate [15]. A significant interaction between $\mathrm{N}_{2} \mathrm{O}$ emissions and soil moisture was also reported for grassland soils [16].

Soil moisture can advance $\mathrm{N}$ mineralization and nitrification through its positive effects on microbial activity, provided that the soil is not saturated and remains aerobic [17]. In this study, additions of nitrogen and increases in precipitation boosted $\mathrm{N}_{2} \mathrm{O}$ emissions by $44.52 \%$. Drying/rewetting events induce an increase in matter cycling in soils and contribute considerably to increased $\mathrm{N}_{2} \mathrm{O}$ emission flux [18]. Furthermore, soil moisture has a dominant role in controlling soil nitrogen cycling and is strongly positively correlated with $\mathrm{N}_{2} \mathrm{O}$ losses [5].
The $\mathrm{N}_{2} \mathrm{O}$ flux enhancement effect on the alpine meadow plot subject to $\mathrm{N} \times$ Pre treatment was lower than that on plots administered either of the two treatments (i.e., $\mathrm{N}$ or Pre) in isolation. The soil water solution acts as a barrier to both $\mathrm{O}_{2}$ and $\mathrm{N}_{2} \mathrm{O}$ diffusion [19]. Agricultural soil has even been found to be an $\mathrm{N}_{2} \mathrm{O}$ sink under anaerobic soil conditions, rich in organic matter and nitrate $[18,19]$. Denitrifying bacteria may use atmospheric $\mathrm{N}_{2} \mathrm{O}$ as an alternative electron acceptor to nitrate, with denitrification to $\mathrm{N}_{2}$ performed as a dominant process [16].

\section{Production Pulses of $\mathrm{N}_{2} \mathrm{O}$ in an Alpine Meadow}

The occurrence of $\mathrm{N}_{2} \mathrm{O}$ erupted pulses after large rainfall events following fertilization of grassland ecosystems was described [13]. The emission pulses (larger than $500 \mu \mathrm{g} \mathrm{m}^{-2} \mathrm{~h}^{-1}$ ) recorded in previous nitrogen fertilization experiments were also found to occur on the alpine meadow (Fig. 2). It was reported that both meadow marsh and fertilized grassland soil had similar peak fluxes, which were approximately 583 and $358 \mu \mathrm{g}$ $\mathrm{m}^{-2} \mathrm{~h}^{-1}$, respectively $[20,21]$. This study revealed that such extreme $\mathrm{N}_{2} \mathrm{O}$ emission release peaks were often evident immediately after each nitrogen fertilization event. On the other hand, in alpine meadows and loess grasslands, the highest pulse peak was always recorded in August [4, 5].

This discrepancy may possibly be ascribed to variations in the nutrient and oxygen concentration profiles of soils [9]. Atmospheric $\mathrm{N}_{2} \mathrm{O}$ moves into the soil via passive diffusion and convection and is then reduced to $\mathrm{N}_{2}$ via denitrification or to $\mathrm{NH}_{3}$ via assimilatory reduction of $\mathrm{N}_{2} \mathrm{O}$ [19]. Within alpine meadows, $\mathrm{N}_{2} \mathrm{O}$ emissions are complex and possibly influenced by multiple factors $[4,9]$. Nitrification has generally been reported to be the dominant process in alpine meadow soils; in theory, however, high soil moisture and optimal soil $\mathrm{pH}$ conditions may also provide good conditions for denitrification to $\mathrm{N}_{2}$ [9].

\section{Conclusion}

The Tibetan Plateau plays an important function in regulating the local climate, and is vulnerable to the nitrogen deposition and precipitation variation. However, these were little data which focused on the $\mathrm{N}_{2} \mathrm{O}$ fluxes subjected to nitrogen addition and increased precipitation in the alpine meadow ecosystem. This study indicated that alpine meadow ecosystem acted as the source of atmosphere $\mathrm{N}_{2} \mathrm{O}$. The nitrogen deposition increased significantly the grassland ecosystem $\mathrm{N}_{2} \mathrm{O}$ emission flux. The significant priming effects were testified after nitrogen fertilization and precipitation application. Furthermore, the precipitation addition could be benefit in mitigating future $\mathrm{N}_{2} \mathrm{O}$ fluxes under the scenarios of global nitrogen deposition. 


\section{Acknowledgements}

This work is supported by the Open Technological Foundation of Key Laboratory of Mountain Hazards and Earth Surface Processes, Institute of Mountain Hazards and Environment, National Natural Science Foundation of China (Nos. 31200379, 31470530), the Natural Science Foundation of Qinghai (No. 2012-Z-921Q), and the China Scholarship Council.

\section{References}

1. HORVÁTH L., GROSZ B., MACHONA., TUBAZ., NAGY Z., CZÓBEL S., FÒTI S., WEIDINGER T. Estimation of nitrous oxide emission from Hungarian semi-arid sandy and loess grasslands; effect of soil parameters, grazing, irrigation and use of fertilizer. Agr. Ecosyst. Environ. 139, 255, 2010.

2. LIU X.J., ZHANG Y., HAN W.X., TANG A.H., SHEN J.L., CUI Z.L., VITOUSEK P., ERISMAN J., GOULDING K., CHRISTIE P. Enhanced nitrogen deposition over China. Nature. 494, 459, 2013.

3. PIAO S.L., CIAIS P., HUANG Y., SHEN Z.H., PENG S.S., LI J.S., ZHOU L.P., LIU H.Y., MA Y.C., DING Y.U., FRIEDLINGSTEIN P., LIU C.Z., TAN K., YU Y.Q., ZHANG T.Y., FANG J.Y. The impacts of climate change on water resources and agriculture in China. Nature. 467, 43, 2010.

4. DU Y.G., CAO G.M., DENG Y.C., SUN G.C., CUI X.Y. Contribution of the vegetation layers in the nitrous oxide emission from alpine Kobresia humilis Serg. meadow ecosystem on the Tibetan Plateau. P. J. Ecol. 58 (3), 115, 2010.

5. JIANG C.M., YU G.R., FANG H.J., CAO G.M., LI Y.N. Short-term effect of increasing nitrogen deposition on $\mathrm{CO}_{2}$, $\mathrm{CH}_{4}$ and $\mathrm{N}_{2} \mathrm{O}$ fluxes in an alpine meadow on the Qinghai -Tibetan Plateau, China. Atmo. Environ. 44, 2920, 2010.

6. SCHEER C., WASSMANN R., KLENZLER R., LBRAGIMOV N., ESCHANOV R. Nitrous oxide emissions from fertilized irrigated cotton(Gossypium hisutum) in the Aral sea basin, Uzbekistan: influence of nitrogen applications and irigation practices. Soil Biol. Biochem. 40, 290, 2008.

7. LI K.H., GONG Y.M., SONG W., LV J.L., CHANG Y.H., HU Y.K., TIAN C.Y., CHRISTIE P, LIU X.J. No significant nitrous oxide emissions during spring thaw under grazing and nitrogen addition in an alpine grassland. Global Change Biol. 18, 2546, 2012.

8. WU Y.B., WU J., DENG Y.C., TAN H.C., DU Y.G., CUI X.Y. Comprehensive assessments of root biomass and production in a Kobresia humilis meadow on the QinghaiTibetan Plateau. Plant Soil. 338, 497, 2011.

9. DU Y.G., CUI Y.G., XU X.L., LIANG D.Y., LONG R.J., CAO G.M. Nitrous oxide emissions from two alpine meadows in the Qinghai-Tibetan Plateau. Plant Soil. 311, $245,2008$.
10. AVRAHAMI S., BOHANNAN B.J.M. $\mathrm{N}_{2} \mathrm{O}$ emission rates in a California meadow soil are influenced by fertilizer level, soil moisture and the community structure of ammoniaoxidizing bacteria. Global Change Biol. 15, 643, 2009.

11. FILIPPA G., FREPPAZ M., WILLIAMS M.W., HELMIG D., LIPTZIN D., SEOK B., HALL B., CHOWANSKI K. Winter and summer nitrous oxide and nitrogen oxides fluxes from a seasonally snow-covered subalpine meadow at Niwot Ridge, Colorado. Biogeochemistry. 95, 131, 2009.

12. SAGGAR S., TATE K.R., GILTRAP D.L., SINGH J. Soilatmosphere exchange of nitrous oxide and methane in New Zealand terrestrial ecosystems and their mitigation options: a review. Plant Soil 309, 25, 2008.

13. ROUX X.L., SCHMID B., POLY F., BARNARD R.L., NIKLAUS P.A., GUILLAUMAUD N., HABEKOST M., OELMANN Y., PHILIPPOT L., SALLES J.F., SCHLOTER M., STEINBEISS S., WEIGELT A. Soil environmental conditions and microbial build-up mediate the effect of plant diversity on soil nitrifying and denitrifying enzyme activities in temperate grasslands. PloS One. 8, e61069, 2013.

14. XU X.L., OUYANG H., PEI Z.P., ZHOU C.P. Long-term partitioning of ammonium and nitrate among different components in an alpine meadow ecosystem. Acta Bot. Sin. 46, 279, 2004 [ In Chinese].

15. SHIMIZU M., HATANO R., ARITA T., KOUDA Y., MORI A., MATSUURA S., NIIMI M., JIN T., DESYATKIN A.R., KAWAMURA O., HOJITO M., MIYATA A. The effect of fertilizer and manure application on $\mathrm{CH}_{4}$ and $\mathrm{N}_{2} \mathrm{O}$ emissions from managed grasslands in Japan. Soil Sci. Plant Nutr. 59, 69, 2013.

16. BERGSTERMANNA., CÁRDENAS L., BOLR., GILLIAM L., GOULDING K., MEIJIDE A., SCHOLEFIELD D., VALLEJO A., WELL R. Effect of antecedent soil moisture conditions on emissions and isotopologue distribution of $\mathrm{N}_{2} \mathrm{O}$ during denitrification. Soil Biol. Biochem. 43, 240, 2011.

17. YANG Y.H., JI C.J., DAVID R., ZHU B., FANG H.J., SHEN H.H., FANG J.Y. Vegetation and soil ${ }^{15} \mathrm{~N}$ natural abundance in alpine grasslands on the Tibetan plateau: patterns and implications. Ecosystems. 16, 1013, 2013.

18. GOLDBERG S.D., GEBAUER G. Drought turns a Central European Norway spruce forest soil from an $\mathrm{N}_{2} \mathrm{O}$ source to a transient $\mathrm{N}_{2} \mathrm{O}$ sink. Global Change Biol. 15, 850, 2009.

19. WU D.M., DONG W.X., OENEMA O., WANG Y.Y., TREBS I., HU C.S. $\mathrm{N}_{2} \mathrm{O}$ consumption by low-nitrogen soil and its regulation by water and oxygen. Soil Biol. Biochem. 60, 165, 2013.

20. SUN Z.G., LIU J.S., YANG J.S., LI X.H., ZHOU W.M. Nitrification-denitrification and $\mathrm{N}_{2} \mathrm{O}$ emission of typical calamagrostis angustifolia wetland soils in Sanjiang plain. China J. Apply Ecol. 18, 185, 2007 [In Chinese].

21. VELTHOF G.L., OENEMA O. Nitrous oxide emission from dairy farming systems in the Netherlands. NJAS-Wagen. J. Life Sci. 45, 347, 1997. 